\title{
RHO-KINASE INHIBITORS - A NEW BROAD-SPECTRUM TREATMENT IN OPHTHALMIC DISEASES. A REVIEW
}

\author{
RALUCA IANCU $^{1,2 \#}$, RUXANDRA PIRVULESCU $^{1,2} *$, SANZIANA ISTRATE ${ }^{1,2 \#}$, ALINA POPA \\ CHERECHEANU ${ }^{1,2}$, GEORGE IANCU $^{1,3}$, MARIAN BURCEA $^{1,4}$
}

\author{
1 "Carol Davila” University of Medicine and Pharmacy, 37 Dionisie Lupu Street, 040292, Bucharest, Romania \\ ${ }^{2}$ Emergency University Hospital Bucharest, 169 Independence Street, 050098, Bucharest, Romania \\ 3 "Filantropia” Clinical Hospital Bucharest, 11-13 Ion Mihalache Street, 011171, Bucharest, Romania \\ ${ }^{4}$ Emergency Ophthalmology Hospital Bucharest, 1 Lahovari Square, 010464, Bucharest, Romania
}

*corresponding author: ruxandra_pascu@yahoo.co.uk

${ }^{*}$ Authors with equal contribution.

Manuscript received: January 2021

\begin{abstract}
Rho-kinases, also called coiled-coil containing protein kinases, are proteins that belong to the guanine triphosphate-ase family. Rho-kinase (ROCK) inhibition represents a relatively new therapeutic target for many diseases as cardiovascular diseases, neuronal degeneration, asthma, cancer. Due to their involvement in multiple biological processes, these compounds are increasingly addressed in the last ten years for clinical trials related to ophthalmic pathologies like glaucoma, endothelial dysfunction and vitreoretinal diseases. ROCK inhibition pathway seems to play important roles in: promoting endothelial cell proliferation and wound healing, regulation of trabecular meshwork outflow, limiting diabetes-induced microvascular damage, inhibiting the development of neovascular choroidal membranes in wet age related macular degeneration. This review of literature explores the mechanisms of action and effects of ROCK inhibitors in a variety of ocular pathologies as corneal pathologies, glaucoma, diabetic retinopathy, age related macular degeneration; also listing clinical trials (completed or ongoing) on ROCK inhibitors administered in patients with those particular disease.
\end{abstract}

\section{Rezumat}

Rho-kinaza, o protein-kinază cu structura helicoidală, este o proteină care aparține familiei guanin-trifosfataze. Inhibarea rhokinazei (ROCK) reprezintă o țintă terapeutică relativ nouă pentru multe afecțiuni precum bolile cardiovasculare, degenerescența neuronală, astmul, cancerul. Datorită implicării lor în multiple procese biologice, acești compuși sunt abordați în ultimii zece ani în studii clinice legate de patologii oftalmice precum glaucomul, disfuncția corneană endotelială și bolile vitreoretiniene. Calea de inhibare a ROCK pare să joace roluri importante în: promovarea proliferării celulelor endoteliale și a vindecării plăgilor, reglarea fluxului din rețeaua trabeculară, limitarea leziunilor microvasculare induse de diabet, inhibarea dezvoltării membranelor coroidiene neovasculare în degenerescența maculară legată de vârsta. Acest articol face o revizuire a literaturii și explorează mecanismele de acțiune și efectele inhibitorilor ROCK într-o varietate de patologii oculare, cum ar fi patologiile corneei, glaucomul, retinopatia diabetică, degenerescența maculară legată de vârstă, enumerând, de asemenea, studiile clinice, finalizate sau în curs.

Keywords: rho-kinase inhibitors, ophthalmology, cornea, glaucoma, diabetic retinopathy, age related macular degeneration

\section{Introduction}

Rho-kinase (ROCK) inhibition represents a relatively new therapeutic target for many diseases as cardiovascular diseases [62], neuronal degeneration [45, 67], asthma [105] and cancer [57]. Due to their involvement in multiple biological processes, these compounds are increasingly addressed in the last ten years for clinical trials related to ophthalmic pathologies as glaucoma, endothelial dysfunction and vitreoretinal diseases. It occurs that ROCK inhibitors can influence the pathological processes in many ocular structures which increased the interest in producing novel drugs that act on corneal epithelium or endothelium, trabecular meshwork, retinal vessels and cells [65, 66]. As a result, selective inhibitors of specific signalling path- ways have been extensively investigated as a potential novel therapy for all these illnesses [54, 59, 81].

\section{ROCK and ROCK inhibitors}

Rho-kinases, also called coiled-coil containing protein kinases, are proteins that belong to the guanine triphosphate-ase (GTPase) family; these molecules are important in a wide variety of biological processes and pathways regarding migration, proliferation, adhesion and contraction [4]. The interaction with these cellular processes is mediated through the GTP state, respectively the switch between an active GTP-bound state and an inactive GTP-bound state $[13,16]$. GTB-bound state activates ROCK and these are also known as effector proteins [18]. Among ROCK proteins two isoforms are 
encountered in humans: ROCK1 and ROCK2. They are members of serine/threonine AGC kinases family and are ubiquitously expressed in all organs, but predominating in some, depending on cell type (ROCK-1 found in non-neuronal tissue as spleen, lung, kidney and liver, and ROCK-2 found in brain, muscle and heart) [29, 82].

Multiple evidences demonstrated that over-expression of ROCK proteins is involved in the pathogenesis of numerous diseases. Inhibition of ROCK showed beneficial effects in animal and human disease models [27]. Among all organs, however, the effect at the ocular level seems to be among the most diverse, influencing multiple ocular structures, thus being able to represent new therapeutic lines for some of the most frequent ophthalmological pathologies.

\section{ROCK inhibitors effect on cornea}

Corneal wound healing seems to be influenced by multiple molecules, among which ATP and lipid mediator lysophosphatidic acid (LPA) were demonstrated to be released from the injured cells to enhance epithelial cell migration and wound healing in the cornea $[97,98,100,102]$. The Rho family regulate actin cytoskeleton, cell migration and proliferation, regulation of cell polarity and gene transcription [28, $42,103]$. ROCK family pathways lead to increase contractility and decrease adhesion $[5,30]$.

Table I

Clinical trials on ROCK inhibitors administered in patients with corneal endothelial cells pathologies

\begin{tabular}{|c|c|c|c|c|}
\hline Trial & Status & Pathologies & Rock inhibitors preparations & Evidence \\
\hline $\begin{array}{c}\text { Moloney et al. } \\
\text { [63] }\end{array}$ & Completed & \begin{tabular}{|c|} 
Patients with Fuchs \\
dystrophy, who underwent \\
central Descemetorhexis not \\
exceeding $4 \mathrm{~mm}$
\end{tabular} & $\begin{array}{l}\text { Two preparations of ROCK } \\
\text { inhibitor were obtained for } \\
\text { trial: Y-27632 at } 10 \mathrm{mM} \text { and } \\
\text { ripasudil hydrochloride hydrate } \\
\text { (Glanatec }{ }^{\circledR} \text { ophthalmic } \\
\text { solution } 0.4 \%) .\end{array}$ & $\begin{array}{c}\text { In Fuchs dystrophy with visual } \\
\text { degradation due to central guttae, } \\
\text { Descemetorhexis without grafting is } \\
\text { a viable procedure for visual } \\
\text { rehabilitation. }\end{array}$ \\
\hline $\begin{array}{l}\text { Moloney et al. } \\
\text { [64] }\end{array}$ & Completed & $\begin{array}{l}\text { Descemet stripping only } \\
\text { With Topical Ripasudil for } \\
\text { Fuchs Endothelial } \\
\text { Dystrophy }\end{array}$ & $\begin{array}{l}\text { Ripasudil } 0.4 \% \text { was applied } \\
\text { topically from day } 1 \text { post- } \\
\text { operatively at a dose of } 6 \text { times } \\
\text { per day until corneal clearance. }\end{array}$ & $\begin{array}{l}\text { This treatment option is emerging as } \\
\text { a reliable intervention for select } \\
\text { patients with Fuchs' Endothelial } \\
\text { Corneal Dystrophy (FECD) with an } \\
\text { acceptable safety profile. }\end{array}$ \\
\hline $\begin{array}{c}\text { Moruyama et } \\
\text { al. }[55]\end{array}$ & Completed & $\begin{array}{l}\text { To investigate the time- } \\
\text { dependent change of corneal } \\
\text { endothelial cell (CEC) } \\
\text { morphology and density } \\
\text { (CECD) in patients with } \\
\text { glaucoma post instillation of } \\
\text { rho-associated protein } \\
\text { kinase inhibitor ripasudil } \\
\text { (Rip) } 0.4 \% \text { eye drops }\end{array}$ & $\begin{array}{l}\text { Ripasudil (Rip) } 0.4 \% \text { eye } \\
\text { drops }\end{array}$ & $\begin{array}{l}\text { Transient morphological changes, } \\
\text { revealed that CEC morphology } \\
\text { gradually recovered to normal } \\
\text { within } 6 \text { hours. }\end{array}$ \\
\hline $\begin{array}{c}\text { Macsai et al. } \\
\text { [53] }\end{array}$ & Completed & $\begin{array}{c}\text { Fuchs corneal dystrophy and } \\
\text { Descemet only streaming }\end{array}$ & $\begin{array}{c}\text { Topical ripasudil } 0.4 \% \\
\left(\text { Glanatec }^{\circledR}\right) 4 \text { times per day } \\
\text { for } 2 \text { months }\end{array}$ & $\begin{array}{l}\text { DSO with topical rho kinase inhibitors } \\
\text { may be an alternative treatment for } \\
\text { patients with FD and a peripheral } \\
\text { ECD greater than } 1000 \text { cells } / \mathrm{mm}^{2} \text {. }\end{array}$ \\
\hline $\begin{array}{l}\text { Alkharashi et } \\
\text { al. [116] }\end{array}$ & Completed & $\begin{array}{l}\text { Cataract surgery/ } \\
\text { Phacoemulsification }\end{array}$ & $\begin{array}{c}\text { Ripasudil (Glanatec } \\
\text { ophthalmic solution } 0.4 \% \text { ) }\end{array}$ & $\begin{array}{c}\text { The use of ROCK inhibitors might } \\
\text { prevent postoperative significant } \\
\text { visual deterioration. }\end{array}$ \\
\hline $\begin{array}{l}\text { Devers Eye } \\
\text { Institute } \\
\text { Portland, } \\
\text { Oregon, } \\
\text { United States } \\
\end{array}$ & Recruiting & \begin{tabular}{|c|} 
Ripasudil for Enhanced \\
Corneal Clearing Following \\
Descemet Membrane \\
Endothelial Keratoplasty in \\
Fuchs' Dystrophy \\
\end{tabular} & $\begin{array}{l}\text { Ripasudil hydrochloride } \\
\text { hydrate (Glanatec }^{\circledR} \\
\text { ophthalmic solution } 0.4 \%)\end{array}$ & $\begin{array}{l}\text { The goal of this study is to test the } \\
\text { potential benefits of Ripasudil } \\
\text { therapy administered after } \\
\text { Descemet Membrane Endothelial } \\
\text { Keratoplasty (DMEK) surgery. }\end{array}$ \\
\hline $\begin{array}{l}\text { Massachusetts } \\
\text { Eye and Ear } \\
\text { Infirmary } \\
\text { Boston, } \\
\text { United States }\end{array}$ & $\begin{array}{c}\text { Completed } \\
\text { January } \\
2021\end{array}$ & \begin{tabular}{|c|} 
Fuchs endothelial dystrophy \\
and cataract to under combined \\
cataract surgery with \\
Descemetorhexis Without \\
Endothelial Keratoplasty
\end{tabular} & $\begin{array}{l}\text { Netarsudil } 0.02 \% \text { ophthalmic } \\
\text { solution }\end{array}$ & to be published \\
\hline
\end{tabular}

Endothelial cells are the key element in the proper function of the cornea. Their inability to mitosis and their vital function in maintaining corneal transparency have led to numerous clinical trials involving the discovery of possible regenerative therapies for endothelial cell loss [46, 71-73, 90, 91].

Fuchs Endothelial Dystrophy and iatrogenic loss of the endothelial cells are some of the most important 
causes for corneal transplantation, an intervention that is not available in many countries [14, 21, 84]. The endothelial cells of the cornea control the cornea hydration, maintaining corneal transparency. The corneal endothelial cell (CEC) density in normal individuals ranges between 2000 and 3000 cells $/ \mathrm{mm}^{2}$, but in pathologic states it can drop under 1000 cells/ $\mathrm{mm}^{2}$ and result in corneal oedema. In state of endothelial cells loss, the remaining cells compensate by migration and spreading. Rho-kinase, by decreasing adhesion and promoting contractility, inhibits this process [59]. There is evidence of expression of ROCK- 1 and ROCK-2 in corneal endothelial cells [59]. ROCK inhibitors play a role in cell cycle and apoptosis [47, 68]. They also seem to promote endothelial cell proliferation and wound healing $[25,70,72]$. In the cornea endothelium apoptotic stimuli are activated by ROCK. ROCK inhibition supresses subsequent cell death [70]. ROCK inhibitors molecules reversibly change the cytoskeleton by the loss of actin stress fibbers, focal cells adhesions and intercellular tight junctions, making possible the migration and proliferation of corneal endothelial cells [59, 66, 78].

Molecules of ROCK inhibitors were extensively researched in vitro and in vivo animal models. Y27632 and H-1152 exhibited significant stimulatory effect on CEC migration and proliferation in vitro [59]. Monolayers of confluent CECs treated with Y-27632 showed a complete collapse of actin cytoskeletal architecture with markedly reduced actin stress fibbers, tight junctions, and cell adhesions [60]. In the corneal endothelial damage rabbit model, more Ki67-positive cells were detected in Y-27632-treated eyes than in control eyes. Actin fibbers were distributed at the cell cortex in the eyes treated with Y-27632, whereas actin distribution was partially disrupted, and stress fibbers were observed in control eyes. Ncadherin and $\mathrm{Na}^{+} / \mathrm{K}^{+}$-ATPase were expressed in almost all cells in Y-27632-treated eyes, but expression decreased in control eyes [74]. Y-27632 and Y-39983 employ both cyclin D and p27 via PI 3-kinase signalling to promote CEC proliferation [75].

To date, no approved pharmacologic therapy exists for corneal endothelial cells dysfunction in humans. In addition to experimental corneal studies in animals, two ROCK inhibitors molecules have also been administered to humans in cases of pathological (Fuchs endothelial dystrophy) or iatrogenic (post phacoemulsification) corneal endothelial damage. Those molecules are Ripasudil and Netarsudil, approved for glaucoma treatment. To date, ongoing clinical trials are using topical treatment with ROCK inhibitors after descemetorexis without endothelial keratoplasty (DWEK), see Table I (ROCK inhibitors administered in patients with corneal endothelial cells pathologies).

\section{ROCK inhibitors and glaucoma}

The most important risk factor that seems to be able to change the evolution of glaucoma is the intraocular pressure, and to date, most treatments have been designed to reduce this pressure, either by decreasing the secretion rate of aqueous humour or by increasing the outflow rate of aqueous humour through the uveoscleral tract $[52,94]$. In addition to these treatments, ROCK inhibitors, through the changes they make on the cells at the trabecular meshwork level (decrease the resistance of this network to the outflow of aqueous humour), further increases the rate of excretion of aqueous humour through the Schlemm's channel, by the conventional pathway [33, 52, 76, 94].

An important role that ROCK inhibitors play in glaucomatous pathology is neuroprotective. By relaxing the smooth muscles of the retinal vascular bed, the blood supply from the retina and the optic nerve increases. It also decreases the degree of apoptosis of retinal ganglion cells and promotes regeneration of their axons [23, 95].

Currently, rho-kinase inhibitors are administered following filtering surgical treatment for glaucoma. Post-trabeculectomy ROCK inhibitors have been shown to have a beneficial effect due to their properties of inhibiting fibroblast proliferation, migration and cell adhesion, thus promoting wound healing and preventing scar formation in the filtering bleb [12, 35].

The first rho-kinase medication approved to treat glaucoma was Ripasudil hydrochloride hydrate $0.4 \%$. This fasudil derivative was first approved in Japan in 2014 under the trade name Glanatec ${ }^{\circledR}$, previously called K-115 [22]. This drug appears to play an important role in attenuating the evolution of glaucoma through its hitherto known mechanisms of action: it increases the outflow of aqueous humour by altering conventional pathways, on one hand, and neuroprotection, on the other [10, 49, 93].

Ripasudil $0.4 \%$ is currently used in patients with POAG, PACG (primary angle closure glaucoma), uveitic glaucoma, steroid-induced glaucoma, exfoliative glaucoma or in patients with ocular hypertension (OHT) and appears to have a beneficial effect in patients with increase in intraocular pressure (IOP) secondary to uveitis $[48,56,58,101]$. It is also administered post-trabeculectomy because a reduction in the incidence of scarring has been observed [19, 24]. The treatment can be given either in monotherapy or as adjunctive therapy in combination with a prostaglandin analogue (which increases uveoscleral outflow) or a $\beta$-blocker (which decreases the rate of aqueous humour production), further decreasing IOP. The recommended dose for Ripasudil $0.4 \%$ is one drop twice a day in the long term for patients with glaucoma or intraocular hypertension. According to specialized studies to date it has been observed that the drug administered alone decreases IOP by about $3.5 \mathrm{mmHg}(2.6 \mathrm{mmHg}$ - 
$3.7 \mathrm{mmHg}$ ), administered in combination with a prostaglandin analogue decreases the additional IOP by approximately $3.2 \mathrm{mmHg}$ and when supplemented with a beta-blocker treatment decreases the IOP by approximately $2.9 \mathrm{mmHg}$ in addition [20, 36-39, 92]. The side effects of Ripasudil documented in the literature were: blepharitis, allergic conjunctivitis, conjunctival hyperaemia and punctate keratitis, transient symptoms that appear to have been dose dependent. Systemic side effects of the drug are rare and often minor (fatigue, headache, dizziness, constipation, nausea, etc.) [20, 36-39, 48, 92].

Another ROCK inhibitor was approved in the United States in 2017 under the trade name Rhopressa ${ }^{\circledR}$ [34]. The active substance identified in the drug is Netarsudil, formerly known as AR-13324, which has both a role as a ROCK inhibitor and a norepinephrine transporter inhibitor, thus having an important effect on the pathogenesis of glaucoma [15, 34].

To date, treatment with Netarsudil has been shown to be effective in open-angle glaucoma and OHT, as it decreases aqueous humour production, reduces episcleral vein pressure and increases aqueous humour outflow through conventional pathways. Used after trabeculectomy filter surgery, this drug decreases the incidence of scarring in the bleb $[26,50]$.
In clinical trials to date, the conclusion was that singledose Netarsudil $0.02 \%$ alone has similar effects on IOP as (do) two drugs such as prostaglandin analogues (once daily) or beta-blockers (twice daily) $[8,9,11$, $41,43,85,96]$. The existence of a fixed combination of Latanoprost $0.005 \%$ and Netarsudil $0.02 \%$ under the trade name Rocklatan ${ }^{\circledR}$ (PG324), given once daily, has led to increased treatment compliance and a further decrease in IOP (approximately $3.5 \mathrm{mmHg}$ ), compared to the administration of a prostaglandin analogue alone $[9,11,96]$.

Patients taking Netarsudil may experience the following side effects: palpebral erythema, blurred vision, conjunctival hyperaemia, subconjunctival haemorrhage, hyper-lacrimation and cornea verticillata $[8,9,11$, 26, 41, 43, 85, 96].

Currently, other ROCK inhibitors have been discovered, but they are still in clinical trials to treat primary or secondary glaucomatous pathology or intraocular hypertension. New agents that are still under study are: SNJ-1656 (formerly known as Y-39983), AR-12286, PHP-201 (also called AMA-0076) and ATS-907. They have been shown to have a beneficial effect on statistically significant IOP-decreasing ocular pathology (Table II) $[86,99,106]$.

Table II

Clinical trials on ROCK inhibitors administered in glaucoma patients

\begin{tabular}{|c|c|c|c|c|}
\hline Trial & Status & Pathologies & \begin{tabular}{|c|}
$\begin{array}{c}\text { Rock inhibitors } \\
\text { preparations }\end{array}$ \\
\end{tabular} & Evidence \\
\hline $\begin{array}{c}\text { Inazaki et al. } \\
\text { [37] }\end{array}$ & Completed & $\begin{array}{c}\text { Adults with open-angle } \\
\text { glaucoma inadequately } \\
\text { controlled with maximum } \\
\text { medical therapy. }\end{array}$ & $\begin{array}{l}\text { Ripasudil Ophthalmic } \\
\text { Solution } 0.4 \%\end{array}$ & $\begin{array}{l}\text { Treatment with ripasudil decreased IOP in } \\
\text { patients with poorly controlled glaucoma } \\
\text { with maximal medical therapy and it was } \\
\text { well-tolerated. }\end{array}$ \\
\hline $\begin{array}{c}\text { Inazaki et al. } \\
\text { [36] }\end{array}$ & Completed & $\begin{array}{c}\text { Adults with open-angle } \\
\text { glaucoma inadequately } \\
\text { controlled with maximum } \\
\text { medical therapy. }\end{array}$ & $\begin{array}{l}\text { Ripasudil Ophthalmic } \\
\text { Solution } 0.4 \%\end{array}$ & $\begin{array}{l}\text { Treatment with ripasudil decreased IOP in } \\
\text { patients with poorly controlled glaucoma } \\
\text { with maximal medical therapy and it was } \\
\text { well-tolerated. }\end{array}$ \\
\hline $\begin{array}{c}\text { Futakuchi et al. } \\
\text { [20] }\end{array}$ & Completed & $\begin{array}{l}\text { Adults with uveitic } \\
\text { glaucoma, exfoliation } \\
\text { glaucoma and steroid- } \\
\text { induced glaucoma. }\end{array}$ & $\begin{array}{c}\text { Ripasudil Ophthalmic } \\
\text { Solution } 0.4 \%\end{array}$ & $\begin{array}{l}\text { Ripasudil administration resulted in a } \\
\text { statistically significant decrease in IOP, with } \\
\text { no statistically significant side effects. These } \\
\text { findings suggest that treatment with ripasudil } \\
\text { is a safe and effective therapeutic modality in } \\
\text { secondary glaucoma. }\end{array}$ \\
\hline $\begin{array}{c}\text { Tanihara et al. } \\
\text { [92] }\end{array}$ & Completed & $\begin{array}{l}\text { Adults with open-angle } \\
\text { glaucoma or ocular } \\
\text { hypertension. }\end{array}$ & $\begin{array}{l}\text { Ripasudil Ophthalmic } \\
\text { Solution } 0.4 \%\end{array}$ & $\begin{array}{l}\text { Administration of } 0.4 \% \text { ripasudil decreased } \\
\text { IOP levels, while at the same time having no } \\
\text { statistically significant side effects when } \\
\text { administered either as monotherapy or as } \\
\text { additive therapy. }\end{array}$ \\
\hline Inoue et al. [38] & Completed & $\begin{array}{l}\text { Adults with open-angle } \\
\text { glaucoma. }\end{array}$ & $\begin{array}{l}\text { Ripasudil Ophthalmic } \\
\text { Solution } 0.4 \%\end{array}$ & $\begin{array}{l}\text { Switching from a PG analogue to PG/timolol } \\
\text { fixed combination eye drops or adding } \\
\text { ripasudil to PG analogue therapy were } \\
\text { equally safe and effective in reducing IOP. }\end{array}$ \\
\hline Asrani et al. [8] & Completed & $\begin{array}{l}\text { Adults with open-angle } \\
\text { glaucoma or ocular } \\
\text { hypertension. }\end{array}$ & \begin{tabular}{|l} 
Fixed-dose combination \\
(FDC) of netarsudil \\
and latanoprost versus \\
monotherapy with \\
netarsudil or latanoprost.
\end{tabular} & $\begin{array}{l}\text { Once daily administration of netarsudil/ } \\
\text { latanoprost FDC achieved a statistically } \\
\text { significant decrease in IOP and was superior } \\
\text { to monotherapy of netarsudil or latanoprost. }\end{array}$ \\
\hline
\end{tabular}


FARMACIA, 2021, Vol. 69, 3

\begin{tabular}{|c|c|c|c|c|}
\hline Trial & Status & Pathologies & $\begin{array}{c}\text { Rock inhibitors } \\
\text { preparations }\end{array}$ & Evidence \\
\hline $\begin{array}{c}\text { Brubaker et al. } \\
\text { [11] }\end{array}$ & Completed & $\begin{array}{l}\text { Adults with open-angle } \\
\text { glaucoma or ocular } \\
\text { hypertension. }\end{array}$ & \begin{tabular}{|c|} 
Fixed-dose combination \\
(FDC) of netarsudil \\
and latanoprost versus \\
monotherapy with \\
netarsudil or latanoprost.
\end{tabular} & $\begin{array}{l}\text { Results at } 12 \text { months revealed superior } \\
\text { efficacy for netarsudil/latanoprost FDC } \\
\text { compared with the individual components, } \\
\text { netarsudil and latanoprost. }\end{array}$ \\
\hline Asrani et al. [9] & Completed & $\begin{array}{l}\text { Adults with open-angle } \\
\text { glaucoma or ocular } \\
\text { hypertension. }\end{array}$ & $\begin{array}{l}\text { Fixed-dose combination } \\
\text { (FDC) of netarsudil } \\
\text { and latanoprost versus } \\
\text { monotherapy with } \\
\text { netarsudil or latanoprost. }\end{array}$ & $\begin{array}{l}\text { The results reveal superior efficacy for } \\
\text { netarsudil/latanoprost FDC compared to the } \\
\text { individual components, netarsudil and } \\
\text { latanoprost, in order to decrease IOP in } \\
\text { glaucoma patients. }\end{array}$ \\
\hline $\begin{array}{c}\text { Walters et al. } \\
\text { [96] }\end{array}$ & Completed & $\begin{array}{l}\text { Adults with open-angle } \\
\text { glaucoma or ocular } \\
\text { hypertension. }\end{array}$ & \begin{tabular}{|c|} 
Fixed-dose \\
combination (FDC) of \\
netarsudil and \\
latanoprost versus \\
monotherapy with \\
netarsudil or \\
latanoprost. \\
\end{tabular} & $\begin{array}{l}\text { Results at } 3 \text { months revealed superior } \\
\text { efficacy for netarsudil/latanoprost FDC } \\
\text { compared with the individual components, } \\
\text { netarsudil and latanoprost and at the same } \\
\text { time greater adherence to treatment. }\end{array}$ \\
\hline $\begin{array}{c}\text { Kahook et al. } \\
\text { [41] }\end{array}$ & Completed & $\begin{array}{l}\text { Adults with open-angle } \\
\text { glaucoma or ocular } \\
\text { hypertension. }\end{array}$ & $\begin{array}{c}\text { Netarsudil Ophthalmic } \\
\text { Solution } 0.02 \%\end{array}$ & $\begin{array}{l}\text { The results at } 12 \text { months revealed that the } \\
\text { administration of Netarsudil had a } \\
\text { statistically significant effect in lowering the } \\
\text { IOP and at the same time was well tolerated } \\
\text { by most patients. }\end{array}$ \\
\hline Singh et al. [85] & Completed & $\begin{array}{c}\text { Adults with open-angle } \\
\text { glaucoma or ocular } \\
\text { hypertension. }\end{array}$ & $\begin{array}{c}\text { Netarsudil Ophthalmic } \\
\text { Solution } 0.02 \%\end{array}$ & $\begin{array}{l}\text { Once daily administration of netarsudil } \\
0.02 \% \text { decreased IOP similarly to patients } \\
\text { receiving timolol } 0.5 \% \text { twice daily. }\end{array}$ \\
\hline $\begin{array}{c}\text { Khouri et al. } \\
\text { [43] }\end{array}$ & Completed & $\begin{array}{c}\text { Adults with open-angle } \\
\text { glaucoma or ocular } \\
\text { hypertension. }\end{array}$ & $\begin{array}{c}\text { Netarsudil Ophthalmic } \\
\text { Solution } 0.02 \%\end{array}$ & $\begin{array}{l}\text { Once daily administration of netarsudil } \\
0.02 \% \text { decreased IOP similarly to patients } \\
\text { receiving timolol } 0.5 \% \text { twice daily. }\end{array}$ \\
\hline $\begin{array}{c}\text { New York } \\
\text { Glaucoma } \\
\text { Research } \\
\text { Institute } \\
{[86,99]}\end{array}$ & $\begin{array}{c}\text { Active, } \\
\text { not } \\
\text { recruiting }\end{array}$ & \begin{tabular}{|c|} 
A Study to Assess the \\
Effect of Rho-Kinase \\
Inhibitor AR-12286 \\
Ophthalmic Solution \\
$0.5 \%$ and $0.7 \%$ in \\
Patients With \\
Uncontrolled Advanced \\
Glaucoma With Prior \\
Failed Trabeculectomy or \\
Tube Shunt \\
\end{tabular} & \begin{tabular}{|c|} 
AR-12286 \\
Ophthalmic Solution \\
$0.5 \%$ and $0.7 \%$ \\
\end{tabular} & $\begin{array}{l}\text { To evaluate the ocular hypotensive efficacy } \\
\text { of the rho-kinase Inhibitor (AR-12286 } 0.5 \% \\
\text { and } 0.7 \% \text { ) ophthalmic solutions in glaucoma } \\
\text { patients with failed prior glaucoma filtering } \\
\text { surgery and uncontrolled IOP who are facing } \\
\text { further surgical intervention. Patients will be } \\
\text { treated for } 6 \text { months in this initial trial. } \\
\text { To evaluate the efficacy of AR-12286 in } \\
\text { enabling treated patients to delay or avoid the } \\
\text { necessity of further surgical intervention. }\end{array}$ \\
\hline $\begin{array}{c}\text { New York } \\
\text { Glaucoma } \\
\text { Research } \\
\text { Institute } \\
{[86,99]}\end{array}$ & $\begin{array}{c}\text { Active, } \\
\text { not } \\
\text { recruiting }\end{array}$ & \begin{tabular}{|c|} 
A Compassionate Case \\
Study to Assess the \\
Hypotensive Efficacy of \\
Rho-Kinase Inhibitor AR- \\
12286 Ophthalmic \\
Solution $0.5 \%$ and $0.7 \%$ \\
in Glaucoma Patients With \\
Uncontrolled Intraocular \\
Pressure to Avoid \\
Surgical Intervention \\
\end{tabular} & \begin{tabular}{|c|} 
AR-12286 \\
Ophthalmic Solution \\
$0.5 \%$ and $0.7 \%$ \\
\end{tabular} & $\begin{array}{l}\text { To evaluate the ocular hypotensive efficacy } \\
\text { of the rho-kinase Inhibitor (AR-12286 } 0.5 \% \\
\text { and } 0.7 \% \text { ) ophthalmic solutions in open-angle } \\
\text { glaucoma patients with uncontrolled IOP who } \\
\text { are facing surgical intervention. Patients will } \\
\text { be treated for } 6 \text { months in this initial trial. } \\
\text { To evaluate the efficacy of AR-12286 in } \\
\text { enabling treated patients to delay or avoid the } \\
\text { necessity of surgical intervention. }\end{array}$ \\
\hline \begin{tabular}{|} 
New York \\
Glaucoma \\
Research \\
Institute, United \\
States \\
{$[86,99]$}
\end{tabular} & $\begin{array}{c}\text { Active, } \\
\text { not } \\
\text { recruiting }\end{array}$ & $\begin{array}{c}\text { A Study to Assess the } \\
\text { Effect of Rho-Kinase } \\
\text { Inhibitor AR-12286 } \\
\text { Ophthalmic Solution } \\
0.5 \% \text { and } 0.7 \% \text { in Patients } \\
\text { With Chronic Angle-closure } \\
\text { Glaucoma (ROCK-CACG) }\end{array}$ & $\begin{array}{c}\text { AR-12286 } \\
\text { Ophthalmic Solution } \\
0.5 \% \text { and } 0.7 \%\end{array}$ & $\begin{array}{l}\text { To evaluate the ocular hypotensive efficacy } \\
\text { of Rho kinase Inhibitor (AR- } 122860.5 \% \text { and } \\
0.7 \% \text { ) ophthalmic solutions in patients } \\
\text { diagnosed with chronic angle-closure } \\
\text { glaucoma treated for } 6 \text { months. }\end{array}$ \\
\hline
\end{tabular}


FARMACIA, 2021, Vol. 69, 3

\begin{tabular}{|c|c|c|c|c|}
\hline Trial & Status & Pathologies & $\begin{array}{c}\text { Rock inhibitors } \\
\text { preparations }\end{array}$ & Evidence \\
\hline $\begin{array}{c}\text { Glaucoma } \\
\text { Associates of } \\
\text { New York, } \\
\text { Robert Ritch, } \\
\text { MD, LLC. } \\
\text { [86, 99] }\end{array}$ & Completed & $\begin{array}{l}\text { A Prospective Study to } \\
\text { Assess the Hypotensive } \\
\text { Efficacy of Rho-Kinase } \\
\text { Inhibitor AR-12286 } \\
\text { Ophthalmic Solution } \\
0.5 \% \text { and } 0.7 \% \text { in Patients } \\
\text { with Exfoliation Syndrome } \\
\text { and Ocular Hypertension } \\
\text { or Glaucoma (ROCK) }\end{array}$ & $\begin{array}{c}\text { AR-12286 } \\
\text { Ophthalmic Solution } \\
0.5 \% \text { and } 0.7 \%\end{array}$ & $\begin{array}{l}\text { This drug is currently being tested in patients } \\
\text { with primary open-angle glaucoma (POAG), } \\
\text { but not yet in glaucoma in exfoliation } \\
\text { syndrome. Because of the mechanism of } \\
\text { glaucoma in XFS and the mechanism of } \\
\text { action of rho-kinase inhibitors, there is reason } \\
\text { to think it would be more effective in eyes } \\
\text { with XFS and glaucoma than in primary } \\
\text { open-angle glaucoma (ordinary glaucoma). }\end{array}$ \\
\hline $\begin{array}{l}\text { United Medical } \\
\text { Research Institute } \\
\text { Inglewood, } \\
\text { California, } \\
\text { United States } \\
\text { Aerie } \\
\text { Pharmaceuticals } \\
\text { [96] }\end{array}$ & Completed & $\begin{array}{l}\text { AR-12286 Fixed Dose } \\
\text { Combination to Lower } \\
\text { Elevated Intraocular } \\
\text { Pressure }\end{array}$ & $\begin{array}{c}\text { AR-12286 } \\
\text { Ophthalmic Solution } \\
0.5 \% \text { and } 0.7 \%\end{array}$ & $\begin{array}{l}\text { This is a double-masked, randomized, } \\
\text { controlled study assessing the safety and } \\
\text { ocular hypotensive efficacy of two AR } \\
\text { 12286/travoprost fixed-dose combination } \\
\text { products compared to Travatan }{ }^{\circledR} \mathrm{Z} \text { in patients } \\
\text { with elevated intraocular pressure }\end{array}$ \\
\hline
\end{tabular}

\section{ROCK inhibitors and diabetic retinopathy}

At present, the mechanisms by which diabetic retinopathy occurs are not fully understood. The pathogenesis is multifactorial and involves microvascular dysfunction in response to ischemia. Damage to endothelial cells and loss of vessel integrity will cause saccular dilation of capillaries and will cause thrombosis, occlusion and degeneration of the capillaries and the appearance of the intra-retinal haemorrhages $[17,88]$. Hyperglycaemia causes ROCK activation which stimulates phosphorylation of myosin regulatory light chain (MLC) [51]. The ROCK pathway activation promotes leukocyte adhesion to the retinal capillaries, thus promoting endothelial damage due to binding to adhesion molecules like ICAM 1 (intercellular adhesion molecule-1) and $\beta_{2}$-integrins $[40,87]$. This leukocyteinduced endothelial damage represents a critical mechanism for diabetic retinopathy development, inducing inflammation and disruption of blood-retinal barrier. These finding reveals that ROCK pathway activation is also involved in diabetic macular oedema through blood-retinal barrier disruption [80, 83]. Additional to leukocyte induced endothelial damage, ROCK signalling also induces direct endothelial damage by inactivating endothelial nitric oxide synthase (eNOS) $[6,65]$. eNOS generates nitric oxide which is a strong vasodilatator and antiapoptotic factor [79]. ROCK pathway is also involved in the pathogenesis of diabetic angiogenesis, VEGF-induced angiogenesis respectively, by stimulating the migration of the endothelial cells and retinal neovascularization [31].

ROCK inhibitors were demonstrated to increase eNOS expression in retinal endothelial cells and limit the leukocyte adhesion [6, 7]. Consequently, ROCK inhibitors seem to limit diabetes-induced microvascular damage [44]. Arita et al. demonstrated the antiangiogenic properties of ROCK inhibitors, due to inhibition of VEGF induced capillary endothelial cell migration and proliferation.

Clinical trials on ROCK inhibitors administered in patients with diabetic retinopa

\begin{tabular}{|c|c|c|c|c|}
\hline Trial & Status & Pathologies & $\begin{array}{c}\text { Rock inhibitors } \\
\text { preparations }\end{array}$ & Evidence \\
\hline $\begin{array}{c}\text { Nourinia, } \\
\text { Ramin } \text { et } \\
\text { al. [69] }\end{array}$ & Completed & $\begin{array}{c}\text { This prospective, interventional } \\
\text { case series included } 15 \text { eyes of } \\
15 \text { patients with diabetic macular } \\
\text { oedema unresponsive to previous } \\
\text { intravitreal bevacizumab (IVB) } \\
\text { injections. }\end{array}$ & $\begin{array}{c}\text { Intravitreal injection } \\
\text { of } 0.025 \mathrm{mg} \text { Fasudil } \\
\text { and } 1.25 \mathrm{mg} \\
\text { Bevacizumab }\end{array}$ & $\begin{array}{l}\text { Visual acuity and central macular thickness } \\
\text { improved statistically significant following } \\
\text { injection. No adverse event was observed } \\
\text { during the study period. Intravitreal ROCK } \\
\text { inhibitors seem to entail structural and visual } \\
\text { benefits in eyes with diabetic macular oedema } \\
\text { refractory to IVB monotherapy. }\end{array}$ \\
\hline $\begin{array}{c}\text { Ahmadieh } \\
\text { H et al. } \\
\text { [1] }\end{array}$ & Completed & $\begin{array}{l}\text { Prospective interventional case } \\
\text { series, patients with persistent } \\
\text { diabetic macular oedema with } \\
\text { macular laser photocoagulation } \\
\text { and multiple intravitreal } \\
\text { bevacizumab injections. }\end{array}$ & \begin{tabular}{|} 
Intravitreal injection \\
of $0.025 \mathrm{mg} / 0.05 \mathrm{~mL}$ \\
Fasudil and \\
intravitreal injection \\
of $1.25 \mathrm{mg} / 0.05 \mathrm{~mL}$ \\
Bevacizumab
\end{tabular} & $\begin{array}{l}\text { Visual acuity and central macular thickness } \\
\text { improved statistically significant following } \\
\text { injection. Combined intravitreal Bevacizumab and } \\
\text { Fasudil injection may have promising effects } \\
\text { in severe cases of diabetic macular oedema } \\
\text { resistant to current therapeutic modalities. }\end{array}$ \\
\hline
\end{tabular}


FARMACIA, 2021, Vol. 69, 3

\begin{tabular}{|c|c|c|c|c|}
\hline Trial & Status & Pathologies & $\begin{array}{c}\text { Rock inhibitors } \\
\text { preparations }\end{array}$ & Evidence \\
\hline $\begin{array}{l}\text { Minami Y } \\
\text { et al. [61] }\end{array}$ & Completed & $\begin{array}{c}\text { Retrospective study in subjects } \\
\text { with glaucoma or ocular hyper- } \\
\text { tension and diabetic retinopathy } \\
\text { with diabetic macular oedema } \\
\text { present before the administration } \\
\text { of Ripasudil }\end{array}$ & $\begin{array}{l}\text { Ripasudil } \\
\text { Ophthalmic } \\
\text { Solution } 0.4 \% \text {, } \\
\text { administered } \\
\text { topically }\end{array}$ & $\begin{array}{l}\text { One month after ripasudil therapy, the mean } \\
\text { foveal thickness decreased significantly. } \\
\text { There was no significant difference in visual } \\
\text { acuity. }\end{array}$ \\
\hline $\begin{array}{l}\text { Ahmadieh } \\
\text { H et al. } \\
\text { [2] }\end{array}$ & Completed & $\begin{array}{c}\text { Prospective randomised clinical } \\
\text { trial with subjects presenting } \\
\text { centre-involving diabetic } \\
\text { macular oedema }\end{array}$ & $\begin{array}{c}\text { Intravitreal } \\
\text { bevacizumab (IVB) } \\
1.25 \mathrm{mg} \text { plus } \\
\text { intravitreal Fasudil } \\
\text { (IVF) } 50 \mu \mathrm{M} / \mathrm{L} \\
\text { versus intravitreal } \\
\text { bevacizumab (IVB) } \\
1.25 \mathrm{mg} .\end{array}$ & $\begin{array}{l}\text { Mean best corrected visual acuity was } \\
\text { significantly improved in both groups at } \\
\text { month } 3(\mathrm{P}<0.001) \text {, but it persisted up to } \\
\text { month } 6 \text { only in the IVB/IVF group. Central } \\
\text { macular thickness was significantly reduced in } \\
\text { both groups at month } 3(\mathrm{p}=0.006, \mathrm{p}<0.001) \text {, } \\
\text { but this reduction sustained only in the IVB/IVF } \\
\text { group up to month } 6(\mathrm{p}<0.001) \text {. }\end{array}$ \\
\hline
\end{tabular}

Recently, several ROCK inhibitors (fasudil, ripasudil) were administered by intravitreal injection, in conjunction with anti-VEGF factors, for persistent diabetic macular oedema (Table III) $[1,61,69]$.

\section{ROCK inhibitors and age related macular degeneration}

Age related macular degeneration (AMD) represents the main cause for low vision in developed countries. There are two clinical forms of AMD, the dry form and the wet form, the las one being characterized by the presence of neovascular membrane of the choroid. In AMD, ROCK pathway is involved in neovascularisation. Age determines an increase signalling of ROCK2; this molecule determines macrophage polarization [104]. It seems that macrophages play an important role in the development of neovascular choroidal membranes in wet AMD [104]. Experimental evidence demonstrates a potential role of ROCK inhibitors in neovascular AMD. In mouse models of neovascular AMD, ROCK inhibitors reduced subretinal fibrosis, but the exact mechanism is not completely understood [32]. To date there are no studies in humans with wet AMD.

\section{Conclusions}

It seems that ROCK inhibitors represent an important pipeline for emerging treatments in ophthalmic pathologies. It is quite remarkable that these molecules can influence pathologies related to cornea, trabecular meshwork, retina and choroid. ROCK inhibitors were FDA approved for treatment of glaucoma and shown good results in many clinical trials. Their usage in cornea and retinal pathologies is under clinical research, with particular good outcomes reported in endothelial disease.

\section{Conflict of interest}

The authors declare no conflict of interest.

\section{References}

1. Ahmadieh H, Nourinia R, Hafezi-Moghadam A, Intravitreal fasudil combined with bevacizumab for persistent diabetic macular edema: a novel treatment. JAMA Ophthalmol., 2013; 131(7): 923-924.

2. Ahmadieh H, Nourinia R, Hafezi-Moghadam A, Sabbaghi H, Nakao S, Zandi S, Yaseri M, Tofighi Z, Akbarian S, Intravitreal injection of a Rho-kinase inhibitor (fasudil) combined with bevacizumab versus bevacizumab monotherapy for diabetic macular oedema: a pilot randomised clinical trial. Br J Ophthalmol., 2019; 103(7): 922-927.

3. Alkharashi M, Al Abbasi O, Magliyah M, Perioperative use of rho-kinase inhibitors has beneficial effect on corneal endothelium after phacoemulsification. Middle East Afr J Ophthalmol., 2019; 26: 246-249.

4. Amano M, Nakayama M, Kaibuchi K, Rho-kinase/ ROCK: a key regulator of the cytoskeleton and cell polarity. Cytoskeleton, 2010; 67(9): 545-554.

5. Anderson S, DiCesare L, Tan I, Leung T, SundarRaj $\mathrm{N}$, Rho-mediated assembly of stress fibers is differentially regulated in corneal fibroblasts and myofibroblasts. Exp Cell Res., 2004; 298(2): 574-583.

6. Arita R, Hata Y, Nakao S, Kita T, Miura M, Kawahara S, Zandi S, Almulki L, Tayyari F, Shimokawa H, Hafezi-Moghadam A, Ishibashi T, Rho kinase inhibition by fasudil ameliorates diabetes-induced microvascular damage. Diabetes, 2009; 58(1): 215-226.

7. Arita R, Hata Y, Ishibashi T, ROCK as a therapeutic target of diabetic retinopathy. J Ophthalmol., 2010; 2010: 175163: 1-9.

8. Asrani S, Robin AL, Serle JB, Lewis RA, Usner DW, Kopczynski CC, Heah T, MERCURY-1 Study Group, Netarsudil/Latanoprost Fixed-Dose Combination for Elevated Intraocular Pressure: Three-Month Data from a Randomized Phase 3 Trial. Am J Ophthalmol., 2019; 207: 248-257.

9. Asrani S, Bacharach J, Holland E, McKee H, Sheng H, Lewis RA, Kopczynski CC, Heah T, Fixed-Dose Combination of Netarsudil and Latanoprost in Ocular Hypertension and Open-Angle Glaucoma: Pooled Efficacy/Safety Analysis of Phase 3 MERCURY-1 and -2. Adv Ther., 2020; 37(4): 1620-1631.

10. Berrino E, Supuran CT, Rho-kinase inhibitors in the management of glaucoma. Expert Opin Ther Pat., 2019; 29(10): 817-827. 
11. Brubaker JW, Teymoorian S, Lewis RA, Usner D, McKee HJ, Ramirez N, Kopczynski CC, Heah T, One Year of Netarsudil and Latanoprost Fixed-Dose Combination for Elevated Intraocular Pressure: Phase 3, Randomized MERCURY-1 Study. Ophthalmol Glaucoma, 2020; 3(5): 327-338.

12. Cheng WS, Chen CL, Chen JT, Lin LT, Pao SI, Chen YH, Lu DW, AR12286 Alleviates TGF- $\beta$-Related Myofibroblast Transdifferentiation and Reduces Fibrosis after Glaucoma Filtration Surgery. Molecules, 2020; 25(19): 4422: 1-19.

13. Cherfils J, Zeghouf M, Regulation of small GTPases by GEFs, GAPs, and GDIs. Physiol Rev., 2013; 93(1): 269-309.

14. Coviltir V, Burcel M, Cherecheanu AP, Ionescu C, Dascalescu D, Potop V, Burcea M, Update on Myopia Risk Factors and Microenvironmental Changes. $J$ Ophthalmol., 2019; 2019: 4960852: 1-9.

15. Dasso L, Al-Khaled T, Sonty S, Aref AA, Profile of netarsudil ophthalmic solution and its potential in the treatment of open-angle glaucoma: evidence to date. Clin Ophthalmol., 2018; 12: 1939-1944.

16. Duman JG, Mulherkar S, Tu YK, Cheng JX, Tolias KF, Mechanisms for spatiotemporal regulation of Rho-GTPase signaling at synapses. Neurosci Lett., 2015; 601: 4-10.

17. Duh EJ, Sun JK, Stitt AW, Diabetic retinopathy: current understanding, mechanisms, and treatment strategies. JCI Insight, 2017; 2(14): e93751: 1-13.

18. Feng Y, LoGrasso PV, Defert O, Li R, Rho kinase (ROCK) inhibitors and their therapeutic potential. $J$ Med Chem., 2016; 59(6): 2269-2300.

19. Futakuchi A, Inoue T, Fujimoto T, Inoue-Mochita M, Kawai M, Tanihara $\mathrm{H}$, The effects of ripasudil (K-115), a Rho kinase inhibitor, on activation of human conjunctival fibroblasts. Exp Eye Res., 2016; 149: 107-115.

20. Futakuchi A, Morimoto T, Ikeda Y, Tanihara H, Inoue $\mathrm{T}$, ROCK-S study group collaborators, Intraocular pressure-lowering effects of ripasudil in uveitic glaucoma, exfoliation glaucoma, and steroid-induced glaucoma patients: ROCK-S, a multicentre historical cohort study. Sci Rep., 2020; 10(1): 10308: 1-11.

21. Gain P, Jullienne R, He Z, Aldossary M, Acquart S, Cognasse F, Thuret G, Global survey of corneal transplantation and eye banking. JAMA Ophthalmol., 2016; 134: 167-173.

22. Garnock-Jones KP, Ripasudil: first global approval. Drugs, 2014; 74(18): 2211-2215.

23. Gauthier AC, Liu J, Neurodegeneration and Neuroprotection in Glaucoma. Yale J Biol Med., 2016; 89(1): 73-79.

24. Goda E, Hirooka K, Mori K, Kiuchi Y, Intraocular pressure-lowering effects of Ripasudil: a potential outcome marker for Trabeculotomy. BMC Ophthalmol., 2019; 19(1): 243: 1-7.

25. Goldstein AS, Aldrich BT, Skeie JM, Schmidt GA, Reed CR, Zimmerman MB, Greiner MA, Assessing the effects of Ripasudil, a novel Rho kinase inhibitor, on human corneal endothelial cell health. $J$ Ocul Pharmacol Ther., 2018; 34(10): 692-699.

26. Gonzalez LE, Boylan PM, Netarsudil for the Treatment of Open-Angle Glaucoma and Ocular Hypertension:
A Literature Review. Ann Pharmacother., 2020; 2021; 55(8): 1-12.

27. Guan R, Xu X, Chen M, Hu H, Ge H, Wen S, Zhou S, $\mathrm{Pi} \mathrm{R}$, Advances in the studies of roles of Rho/Rhokinase in diseases and the development of its inhibitors. Eur J Med Chem., 2013; 70: 613-622.

28. Hall A, Rho GTPases and the actin cytoskeleton. Science, 1998; 279(5350): 509-514.

29. Hartmann S, Ridley AJ, Lutz S, The Function of Rho-Associated Kinases ROCK1 and ROCK2 in the Pathogenesis of Cardiovascular Disease. Front Pharmacol., 2015; 6: 276: 1-16.

30. Harvey SAK, Anderson SC, SundarRaj N, Downstream effects of ROCK signaling in cultured human corneal stromal cells: microarray analysis of gene expression. Investig Opthalmol Vis Sci., 2004; 45(7): 2168-2176.

31. Hoang MV, Whelan MC, Senger DS, Rho activity critically and selectively regulates endothelial cell organization during angiogenesis. Proc Natl Acad Sci USA., 2004; 101(7): 1874-1879.

32. Hollanders K, Van Bergen T, Kindt N, Castermans K, Leysen D, Vandewalle E, Moons L, Stalmans I, The effect of AMA0428, a novel and potent ROCK inhibitor, in a model of neovascular age-related macular degeneration. Invest Ophthalmol Vis Sci., 2015; 56(2): 1335-1348.

33. Honjo M, Tanihara H, Inatani M, Kido N, Sawamura T, Yue BY, Narumiya S, Honda Y, Effects of rhoassociated protein kinase inhibitor Y-27632 on intraocular pressure and outflow facility. Invest Ophthalmol Vis Sci., 2001; 42(1): 137-144.

34. Hoy SM, Netarsudil Ophthalmic Solution 0.02\%: First Global Approval. Drugs, 2018; 78(3): 389-396.

35. Ibrahim DG, Ko JA, Iwata W, Okumichi H, Kiuchi Y, An in vitro study of scarring formation mediated by human Tenon fibroblasts: Effect of Y-27632, a Rho kinase inhibitor. Cell Biochem Funct., 2019; 37(2); 113-124.

36. Inazaki H, Kobayashi S, Anzai Y, Satoh H, Sato S, Inoue $\mathrm{M}$, Yamane $\mathrm{S}$, Kadonosono $\mathrm{K}$, Efficacy of the additional use of ripasudil, a rho-kinase inhibitor, in patients with glaucoma inadequately controlled under maximum medical therapy. J Glaucoma, 2017; 26(2): 96-100.

37. Inazaki H, Kobayashi S, Anzai $Y$, Satoh H, Sato S, Inoue M, Yamane S, Kadonosono K, One-year efficacy of adjunctive use of Ripasudil, a rho-kinase inhibitor, in patients with glaucoma inadequately controlled with maximum medical therapy. Graefes Arch Clin Exp Ophthalmol., 2017; 255(10): 2009-2015.

38. Inoue $\mathrm{K}$, Ishida $\mathrm{K}$, Tomita $\mathrm{G}$, Effectiveness and safety of switching from prostaglandin analog monotherapy to prostaglandin/timolol fixed combination therapy or adding ripasudil. Jpn J Ophthalmol., 2018; 62(4): 508-516.

39. Irimia $\mathrm{T}$, Muşat GC, Prisada RM, Ghica MV, DinuPîrvu CE, Anuța V, Velescu BS, Popa L, Contributions on formulation and preliminary evaluation of ocular colloidal systems of chitosan and poloxamer 407 with bupivacaine hydrochloride. Farmacia, 2019; 67(4): 702-708.

40. Joussen AM, Murata T, Tsujikawa A, Kirchhof B, Bursell SE, Adamis AP, Leukocyte-mediated endothelial 
cell injury and death in the diabetic retina. $A m J$ Pathol., 2001; 158(1): 147-152.

41. Kahook MY, Serle JB, Mah FS, Kim T, Raizman MB, Heah T, Ramirez-Davis N, Kopczynski CC, Usner DW, Novack GD, ROCKET-2 Study Group, Long-term Safety and Ocular Hypotensive Efficacy Evaluation of Netarsudil Ophthalmic Solution: Rho Kinase Elevated IOP Treatment Trial (ROCKET-2). Am J Ophthalmol., 2019; 200: 130-137.

42. Kaibuchi K, Kuroda S, Amano M, Regulation of the cytoskeleton and cell adhesion by the Rho family GTPases in mammalian cells. Annu Rev Biochem., 1999; 68: 459-486.

43. Khouri AS, Serle JB, Bacharach J, Usner DW, Lewis RA, Braswell P, Kopczynski CC, Heah T, Rocket-4 Study Group, Once-Daily Netarsudil Versus TwiceDaily Timolol in Patients With Elevated Intraocular Pressure: The Randomized Phase 3 ROCKET-4 Study. Am J Ophthalmol., 2019; 204: 97-104.

44. Kita T, Hata Y, Arita R, Kawahara S, Miura M, Nakao S, Mochizuki Y, Enaida H, Goto Y, Shimokawa H, Hafezi-Moghadam A, Ishibashi T, Role of TGF- $\beta$ in proliferative vitreoretinal diseases and ROCK as a therapeutic target. Proc Natl Acad Sci USA., 2008; 105(45): 17504-17509.

45. Koch JC, Tatenhorst L, Roser AE, Saal KA, Tönges L, ROCK inhibition in models of neurodegeneration and its potential for clinical translation. Pharmacol Ther., 2018; 189: 1-21.

46. Koizumi N, Okumura N, Kinoshita S, Development of new therapeutic modalities for corneal endothelial disease focused on the proliferation of corneal endothelial cells using animal models. Exp Eye Res., 2012; 95(1): 60-67.

47. Koyanagi M, Takahashi J, Arakawa Y, Doi D, Fukuda H, Hayashi H, Narumiya S, Hashimoto N, Inhibition of the Rho/ROCK pathway reduces apoptosis during transplantation of embryonic stem cell-derived neural precursors. J Neurosci Res., 2008; 86(2): 270-280.

48. Kusuhara S, Katsuyama A, Matsumiya W, Nakamura M, Efficacy and safety of ripasudil, a Rho-associated kinase inhibitor, in eyes with uveitic glaucoma. Graefes Arch Clin Exp Ophthalmol., 2018; 256(4): 809-814.

49. Kusuhara S, Nakamura M, Ripasudil hydrochloride hydrate in the treatment of glaucoma: safety, efficacy, and patient selection. Clin Ophthalmol., 2020; 14: 1229-1236.

50. Lin CW, Sherman B, Moore LA, Laethem CL, Lu DW, Pattabiraman PP, Rao PV, deLong MA, Kopczynski CC, Discovery and preclinical development of netarsudil, a novel ocular hypotensive agent for the treatment of glaucoma. J Ocul Pharmacol Ther., 2018; 34(1-2): 40-51.

51. Lu QY, Chen W, Lu L, Zheng Z, Xu X, Involvement of RhoA/ROCK1 signaling pathway in hyperglycemiainduced microvascular endothelial dysfunction in diabetic retinopathy. Int J Clin Exp Pathol., 2014; 7(10): 7268-7277.

52. Lusthaus J, Goldberg I, Current management of glaucoma. Med J Aust., 2019; 210(4): 180-187.

53. Macsai MS, Shiloach M, CCRP Use of Topical Rho Kinase Inhibitors in the Treatment of Fuchs Dystrophy After Descemet Stripping Only. Cornea, 2019; 38(5): 529-534.
54. Barac IR, Balta G, Zemba M, Branduse L, Mehedintu C, Burcea M, Barac DA, Branisteanu DC, Balta F, Accelerated vs. conventional collagen cross-linking for infectious keratitis. Exp Ther Med., 2021; 21(3): 285: 1-4.

55. Maruyama Y, Ikeda Y, Mori K, Yoshii K, Ueno M, Yoshikawa H, Sotozono C, Kinoshita S, Morphological change and recovery of corneal endothelial cells after rho-associated protein kinase inhibitor eye-drop (ripasudil 0.4\%) instillation. Br J Ophthalmol., 2021; 105(2): 169-173.

56. Maruyama Y, Ikeda Y, Mori K, Yoshii K, Ueno M, Sotozono C, Kinoshita S, Safety and efficacy of long-term ripasudil $0.4 \%$ instillation for the reduction of intraocular pressure in Japanese open-angle glaucoma patients. J Ocul Pharmacol Ther., 2020; 36(4): 229-233.

57. Matsubara M, Bissell MJ, Inhibitors of Rho kinase (ROCK) signaling revert the malignant phenotype of breast cancer cells in 3D context. Oncotarget, 2016; 7(22): 31602-31622.

58. Matsumura R, Inoue $T$, Matsumura A, Tanihara $H$, Efficacy of Ripasudil as a Second-line Medication in Addition to a Prostaglandin Analog in Patients with Exfoliation Glaucoma: A Pilot Study. Clin Drug Investig., 2017; 37(6): 535-539.

59. Meekins LC, Rosado-Adames N, Maddala R, Zhao JJ, Rao PV, Afshari NA, Corneal Endothelial Cell Migration and Proliferation Enhanced by Rho Kinase (ROCK) Inhibitors in In Vitro and In Vivo Models. Invest Ophthalmol Vis Sci., 2016; 57(15): 6731-6738.

60. Meekins LC, Rosado-Adames N, Maddala R, Epstein DL, Rao V, Afshari NA, Corneal Endothelial Cell Migration and Proliferation Enhanced by Rho Kinase (ROCK) Inhibitors and Statins. Invest Ophthalmol Vis Sci., 2012; 53(14): 6017.

61. Minami Y, Song YS, Ishibazawa A, Omae T, Ro-Mase T, Ishiko S, Yoshida A, Effect of ripasudil on diabetic macular edema. Sci Rep., 2019; 9(1): 3703: 1-5.

62. Ming Dong, Bryan P Yan, James K Liao, Yat-Yin Lam, Gabriel WK Yip, Cheuk-Man Yu, Rho-kinase inhibition: a novel therapeutic target for the treatment of cardiovascular diseases. Drug Discovery Today, 2010; 15(15-16): 622-629.

63. Moloney G, Petsoglou C, Ball M, Kerdraon Y, Höllhumer R, Spiteri N, Beheregaray S, Hampson J, D'Souza M, Devasahayam RN, Descemetorhexis without grafting for Fuchs endothelial dystrophysupplementation with topical ripasudil. Cornea, 2017; 36(6): 642-648.

64. Moloney G, Garcerant Congote D, Hirnschall N, Arsiwalla T, Boso ALM, Toalster N, D'Souza M, Devasahayam RN, Descemet stripping only supplemented with topical ripasudil for Fuchs endothelial dystrophy 12-month outcomes of the Sydney Eye Hospital Study. Cornea, 2021; 40(3): 320-326.

65. Moshirfar M, Parker L, Birdsong OC, Ronquillo YC, Hofstedt D, Shah TJ, Gomez AT, Sr Hoopes PC, Use of Rho kinase inhibitors in ophthalmology: a review of the literature. Med Hypothesis Discov Innov Ophthalmol, 2018; 7(3): 101-111.

66. Moura-Coelho N, Ferreira JT, Bruxelas CP, DutraMedeiros M, Cunha JP, Proença RP, Rho kinase inhibitors $-\mathrm{A}$ review on the physiology and clinical use 
FARMACIA, 2021, Vol. 69, 3

in Ophthalmology. Graefes Arch Clin Exp Ophthalmol., 2019; 257(6): 1101-1117.

67. Mulherkar S, Tolias KF, RhoA-ROCK signaling as a therapeutic target in traumatic brain injury. Cells, 2020; 9(1): 245: 1-13.

68. Noritake K, Aki T, Funakoshi T, Unuma K, Nara A, Kato C, Uemura K, Critical roles of Rho-associated kinase in membrane blebbing and mitochondrial pathway of apoptosis caused by 1-butanol. Toxicol In Vitro, 2012; 26(6): 849-855.

69. Nourinia R, Ahmadieh H, Shahheidari MH, Zandi S, Nakao S, Hafezi-Moghadam A, Intravitreal fasudil combined with bevacizumab for treatment of refractory diabetic macular edema; a pilot study. J Ophthalmic Vis Res., 2013; 8(4): 337-340.

70. Okumura N, Fujii K, Kagami T, Makiko N, Kitahara M, Kinoshita S, Koizumi N, Activation of the Rho/Rho kinase signaling pathway is involved in cell death of corneal endothelium. Invest Ophthalmol Vis Sci., 2016; 57(15): 6843-6851.

71. Okumura N, Koizumi N, Ueno M, Sakamoto Y, Takahashi H, Hirata K, Torii R, Hamuro J, Kinoshita $\mathrm{S}$, Enhancement of corneal endothelium wound healing by Rho-associated kinase (ROCK) inhibitor eye drops. Br J Ophthalmol., 2011; 95(7): 1006-1009.

72. Okumura N, Okazaki Y, Inoue R, Kakutani K, Nakano S, Kinoshita S, Koizumi N, Effect of the Rho associated kinase inhibitor eye drop (ripasudil) on corneal endothelial wound healing. Invest Ophthalmol Vis Sci., 2016; 57(3):1284-1292.

73. Okumura N, Ueno M, Koizumi N, Sakamoto Y, Hirata $\mathrm{K}$, Hamuro J, Kinoshita S, Enhancement on primate corneal endothelial cell survival in vitro by a ROCK inhibitor. Invest Ophthalmol Vis Sci., 2009; 50(8): 3680-3687.

74. Okumura N, Inoue R, Okazaki Y, Nakano S, Nakagawa H, Kinoshita S, Koizumi N, Effect of the Rho Kinase Inhibitor Y-27632 on Corneal Endothelial Wound Healing. Invest Ophthalmol Vis Sci., 2015; 56(10): 6067-6074.

75. Okumura N, Nakano S, Kay EDP, Numata R, Ota A, Sowa Y, Sakai T, Ueno M, Kinoshita S, Koizumi N, Involvement of Cyclin D and p27 in Cell Proliferation Mediated by ROCK Inhibitors Y-27632 and Y-39983 During Corneal Endothelium Wound Healing. Invest Ophthalmol Vis Sci., 2014; 55(1): 318-329.

76. Ota C, Ida Y, Ohguro H, Hikage F, ROCK inhibitors beneficially alter the spatial configuration of TGF 32 treated 3D organoids from a human trabecular meshwork (HTM). Sci Rep., 2020; 10(1): 20292: 1-11.

77. Peh GSL, Adnan K, George BL, Ang HP, Seah XY, Tan DT, Mehta JS, The effects of Rho-associated kinase inhibitor Y-27632 on primary human corneal endothelial cells propagated using a dual media approach. Sci Rep., 2015; 5: 9167: 1-10.

78. Pipparelli A, Arsenijevic Y, Thuret G, Gain P, Nicolas M, Majo F, ROCK inhibitor enhances adhesion and wound healing of human corneal endothelial cells. PLoS One, 2013; 8(4): e62095: 1-19.

79. Rossig L, Haendeler J, Hermann C, Malchow P, Urbich C, Zeiher AM, Dimmeler S, Nitric oxide downregulates MKP-3 mRNA levels: involvement in endothelial cell protection from apoptosis. $J$ Biol Chem., 2000; 275(33): 25502- 25507.
80. Rothschild PR, Salah S, Berdugo M, Gélizé E, Delaunay K, Naud MC, Klein C, Moulin A, Savoldelli M, Bergin C, Jeanny JC, Jonet L, Arsenijevic Y, Behar-Cohen F, Crisanti P, ROCK-1 mediates diabetes-induced retinal pigment epithelial and endothelial cell blebbing: Contribution to diabetic retinopathy. Sci Rep., 2017; 7(1): 8834: 1-15.

81. Scheau C, Mihai LG, Bădărău AI, Căruntu C, Emerging applications of some important natural compounds in the field of oncology. Farmacia, 2020; 68(3): 984-991.

82. Seccia TM, Rigato M, Ravarotto V, Calò LA, ROCK (RhoA/Rho kinase) in cardiovascular-renal pathophysiology: A review of new advancements. J Clin Med., 2020; 9(5): 1328: 1-13.

83. Shahsuvaryan ML, Diabetic Retinopathy: The Promise of New Druggable Target. EC Ophthalmology, 2020; SI.02: 04-09.

84. Shtein RM, Raoof-Daneshvar D, Lin HC, Sugar A, Mian SI, Nan B, Stein JD, Keratoplasty for corneal endothelial disease 2001-2009. Ophthalmology, 2012; 119(7): 1303-1310.

85. Singh IP, Fechtner RD, Myers JS, Kim T, Usner DW, McKee H, Sheng H, Lewis RA, Heah T, Kopczynski CC, Pooled Efficacy and Safety Profile of Netarsudil Ophthalmic Solution $0.02 \%$ in Patients With Openangle Glaucoma or Ocular Hypertension. J Glaucoma, 2020; 29(10): 878-884.

86. Skaat A, Jasien JV, Ritch R, Efficacy of Topically Administered Rho-Kinase Inhibitor AR-12286 in Patients with Exfoliation Syndrome and Ocular Hypertension or Glaucoma. J Glaucoma, 2016; 25(9): e807-814.

87. Smith CW, Marlin SD, Rothlein R, Toman C, Anderson DC, Cooperative interactions of LFA-1 andMac-1 with intracellular adhesion molecule-1 in facilitating adherence and transendothelial migration of human neutrophils in vitro. J Clin Invest., 1989; 83(6): 2008-2017.

88. Stitt AW, Curtis TM, Chen M, Medina RJ, McKay GJ, Jenkins A, Gardiner TA, Lyons TJ, Hammes HP, Simó R, Lois N, The progress in understanding and treatment of diabetic retinopathy. Prog Retin Eye Res., 2016; 51: 156-186.

89. Sun CC, Chiu HT, Lin YF, Lee KY, Pang JHS, Y27632, a ROCK Inhibitor, Promoted Limbal Epithelial Cell Proliferation and Corneal Wound Healing. PLoS One, 2015; 10(12): e0144571: 1-18.

90. Tamura M, Nakao H, Yoshizaki H, Shiratsuchi M, Shigyo H, Yamada H, Ozawa T, Totsuka J, Hidaka $\mathrm{H}$, Development of specific Rho-kinase inhibitors and their clinical application. Biochim Biophys Acta, 2005; 1754(1-2): 245-252.

91. Tan D, Dart J, Holland E, Kinoshita S, Corneal transplantation. Lancet, 2012; 379(9827): 1749-1761.

92. Tanihara H, Inoue T, Yamamoto T, Kuwayama Y, Abe H, Fukushima A, Suganami H, Araie M, K115 Clinical Study Group, One-year clinical evaluation of $0.4 \%$ ripasudil $(\mathrm{K}-115)$ in patients with open-angle glaucoma and ocular hypertension. Acta Ophthalmol., 2016; 94(1): e26-e34.

93. Testa V, Ferro Desideri L, Della Giustina P, Traverso $\mathrm{CE}$, Iester M, An update on ripasudil for the treatment 
of glaucoma and ocular hypertension. Drugs Today (Barc)., 2020; 56(9): 599-608.

94. Twa MD, Intraocular Pressure and Glaucoma. Optom Vis Sci., 2018; 95(2): 83-85.

95. Van de Velde S, De Groef L, Stalmans I, Moons L, Towards axonal regeneration and neuroprotection in glaucoma: Rho kinase inhibitors as promising therapeutics. Prog Neurobiol., 2015; 131: 105-119.

96. Walters TR, Ahmed IIK, Lewis RA, Usner DW, Lopez J, Kopczynski CC, Heah T, MERCURY-2 Study Group, Once-Daily Netarsudil/Latanoprost Fixed-Dose Combination for Elevated Intraocular Pressure in the Randomized Phase 3 MERCURY-2 Study. Ophthalmol Glaucoma, 2019; 2(5): 280-289.

97. Wang DA, Du H, Jaggar JH, Brindley DN, Tigyi GJ, Watsky MA, Injury-elicited differential transcriptional regulation of phospholipid growth factor receptors in the cornea. Am J Physiol Cell Physiol., 2002; 283(6): C1646-C1654.

98. Watsky MA, Griffith M, Wang DA, Tigyi GJ, Phospholipid growth factors and corneal wound healing. Ann NY Acad Sci., 2000; 905: 142-158.

99. Williams RD, Novack GD, van Haarlem T, Kopczynski C, AR-12286 Phase 2A Study Group, Ocular hypotensive effect of the Rho kinase inhibitor AR-12286 in patients with glaucoma and ocular hypertension. Am J Ophthalmol., 2011; 152(5): 834-841.e1.

100. Xu KP, Yin J, Yu FS, Lysophosphatidic acid promoting corneal epithelial wound healing by transactivation of epidermal growth factor receptor. Invest Ophthalmol Vis Sci., 2007; 48(2): 636-643.
101. Yasuda M, Takayama K, Kanda T, Taguchi M, Someya $\mathrm{H}$, Takeuchi M, Comparison of intraocular pressurelowering effects of ripasudil hydrochloride hydrate for inflammatory and corticosteroid-induced ocular hypertension. PLoS One, 2017; 12(10): e0185305: 1-11.

102. Yin J, Xu K, Zhang J, Kumar A, Yu FSX, Woundinduced ATP release and EGF receptor activation in epithelial cells. J Cell Sci., 2007; 120(Pt 5): 815-825.

103. Yin J, Yu FSX, Rho kinases regulate corneal epithelial wound healing. Am J Physiol Cell Physiol., 2008; 295(2): C378-C387.

104. Zandi S, Nakao S, Chun KH, Fiorina P, Sun D, Arita R, Zhao M, Kim E, Schueller O, Campbell S, Taher M, Melhorn MI, Schering A, Gatti F, Tezza S, Xie F, Vergani A, Yoshida S, Ishikawa K, Yamaguchi M, Sasaki F, Schmidt-Ullrich R, Hata Y, Enaida H, Yuzawa M, Yokomizo T, Kim YB, Sweetnam P, Ishibashi T, Hafezi-Moghadam A, ROCK-isoformspecific polarization of macrophages associated with age-related macular degeneration. Cell Rep., 2015; 10(7): 1173-1186.

105. Zhang Y, Saradna A, Ratan R, Ke X, Tu W, Do DC, $\mathrm{Hu} \mathrm{C}$, Gao P, RhoA/Rho-kinases in asthma: from pathogenesis to therapeutic targets. Clin Transl Immunol., 2020; 9(5): e1134: 1-16.

106. Zhou EH, Paolucci M, Dryja TP, Manley T, Xiang C, Rice DS, Prasanna G, Chen A, A Compact WholeEye Perfusion System to Evaluate Pharmacologic Responses of Outflow Facility. Invest Ophthalmol Vis Sci., 2017; 58(7): 2991-3003. 